\title{
Decentering Law and Empire: Law-Making, Local Normativities, and the Iberian Empires in Asia
}

\author{
Manuel Bastias Saavedra
}

\section{Introduction}

Although they constantly shape behavior and nudge people to act in certain ways, norms tend to be taken for granted. Taking off shoes or removing a hat when entering a sacred space are not merely the result of individual decisions made upon crossing the threshold of a temple; they are appropriate ways of acting in that specific context and they signal conformity with a norm. This can also be noticed when one does not know the appropriate behavior and so looks around for social cues: if others take off their shoes, it may perhaps be appropriate to do so too-even if we do not know why. In this sense, norms have a way of being always present yet going unnoticed; that is, until a violation exposes our normative expectations. For example, social faux pas, such as arriving underdressed to a cocktail party or overdressed to an informal gathering, only once they happen, reveal that conventions and expectations have been offended. Beyond the transitory embarrassment, the consequences of such violations are not necessarily grave. But the offence itself shows that, until then, everyone else at the gathering had been observing an implicit and intuitive norm. And besides those that are implicitly and intuitively followed, conventions, standards, commandments, rules, and laws, among innumerable others, are also norms that are-to a greater or lesser extent-institutionalized or explicitly stated.

As they tend to structure behaviors, utterances, and practices, historians have long confronted the question of whether it is possible to study norms at all. On the one hand, historical sources reveal what people said and did, but they rarely show what they believed, thought, or understood while saying and doing so. On the other hand, since norms are pervasive and are grounded in culture and experience, people do not simply act arbitrarily, instead operating by following norms and evaluating the consequences of offending them. These norms can thus be reconstructed through historical sources with careful 
attention to the practices. ${ }^{1}$ This latter approach can be said to focus on normativity: instead of merely seeking to describe what people said and did, it uses these behaviors and utterances as ways of looking into their broader normative content. To use some examples from this volume, wearing a hat when attending mass, providing shelter to missionaries, or deciding on the date of a wedding are all actions and decisions which can be simply described as such, but they can also be described as complying with or defying explicit or implicit normative expectations. And, often, acting in a certain way or saying certain things is not as straightforward as it seems, but in fact pits interests against norms, as well as different kinds of norms against each other. Accordingly, looking at normativity means paying attention to both the factuality and the normative meanings attached to different practices, behaviors, and utterances.

The sharp distinction between norms and practices has certainly been shaped by the contemporary difference between legal norms and other kinds of norms (social, moral, religious, etc.). This difference, however, is relatively recent. Early modern European law was a complex repository of norms that not only included laws, edicts, and ordinances, but also encompassed a wide range of habits, conventions, customs, values, and moral instructions. The production of norms was not centralized in the hands of political power, and explicitly formulated laws were not the only norms that composed the corpus of law. Instead, law was understood to be spontaneously produced through social life; longstanding traditions, conventions, habits, and other social norms were understood to derive their validity from the mere fact that they were followed. In this sense, "the juridical sphere and that of factuality tended to merge; the dimension of 'validity' ceded to that of 'efficacy".'2 Norms were thus not imposed on social reality, but derived from it. Practices, social mores, and the status quo - as a prevailing factual order - were, in and of themselves, considered to have a deep juridical undergirding in their quality of, ultimately, having derived from divine creation. The hypostatization of the distinctions between legal and non-legal norms, between facts and norms, and between norms and practices is a phenomenon of perhaps only the last 250 years, during which time law was reimagined as a purely normative sphere, detached from social life more generally.

The distinction between legal and non-legal norms has since created a kind of disciplinary division of labor. While anthropologists and sociologists have

1 In a recent debate, these positions have been argued, respectively, by Lauren Benton and Tamar Herzog in their contributions in: Owensby and Ross (eds.), Justice in a New World: Negotiating Legal Intelligibility in British, Iberian, and Indigenous America.

2 Grossi, El Orden Jurídico Medieval, 75 . All translations in this chapter are mine. 
focused on rituals, taboos, social roles, institutions, religious and cultural practices, habitus, and a wide variety of informal and non-legal norms anchored in social practices, the world of formal law became the focus of legal scholars, legal theorists, and legal historians. Social and cultural historians, for their part, have moved between these disciplinary boundaries but have not always successfully recognized the normativity of social life nor the factual dimension of the legal system. This division of labor, however, has been slowly but steadily eroded in recent decades by interdisciplinary approaches from legal sociology to legal pluralism. Recent legal-historical approaches have further moved to dissolve the distinction between legal and non-legal norms, which had become increasingly problematic as research began to favor global historical perspectives by moving toward studying normativity and the production of normative knowledge. ${ }^{3}$ Understanding the ways in which decentralized processes of normative production occurred in different times and places is now increasingly the focus of a global legal history. ${ }^{4}$

This volume, as a contribution to this effort, looks at the way in which norms were constructed in the Iberian empires in Asia. The arrival of the Portuguese in Calicut in 1498 and the Castilians in Cebu in 1521 transformed the Iberian age of explorations into a decidedly global enterprise. In little more than a century, between 1415 and 1529, what had begun as a struggle between Portugal and Castile to control the islands and positions gained in West Africa and the Atlantic turned into a transoceanic competition to reach the Indies and secure control of the Spice Islands of Ternate and Tidore, on the other side of the globe. While the Portuguese quickly set about laying the foundations of their Estado da Índia, as the Portuguese empire in Asia came to be known, ${ }^{5}$ Castilians would only begin to establish secure footing in the region once Andrés de Urdaneta finally discovered the return route between the Philippines and New Spain, across the Pacific, in $1565 .{ }^{6}$ This era of long-distance voyages would inaugurate the centuries-long presence of the Iberian empires in Asia characterized by tenuous, disparate, and fragmented jurisdictions with many centers that connected settlements, goods, persons, and institutions across the Atlantic, the Pacific, and the Indian oceans.

3 Duve, "What is Global Legal History?”; Duve, “Rechtsgeschichte als Geschichte von Normativitätswissen?".

4 This is the focus of the joint project 'Glocalizing Normativities: A Global Legal History (15th-21st centuries)' carried out at the Max Planck Institute for Legal History and Legal Theory.

5 Disney, The Portuguese in India and other Studies, 1500-1700; Subrahmanyam, The Portuguese Empire in Asia, 1500-1700: A Political and Economic History; Thomaz, De Ceuta a Timor.

6 Gruzinski, Las Cuatro Partes del Mundo: Historia de una Mundialización; Spate, The Spanish Lake. 
The complex geopolitics of the region, the articulation of secular and religious interests, and the combination of formal and informal enterprises make the expansion of the Iberian empires in Asia an excellent backdrop for the study of normative production and change. First, Portuguese and Castilians encountered well-established trade networks and competed for influence with numerous powerful empires. Though the Portuguese were quite successful in securing control of navigation and commerce in the Indian Ocean, from East Africa to the Moluccas, the presence of important competing empires, such as the Mughals, the Safavids, the Ottomans, the Ming, and the Vijayanagara, limited their territorial control to small territorial enclaves that articulated spaces of supply (Goa), strategic outposts (Malacca and Hormuz), and areas of logistic importance (Mozambique). ${ }^{7}$ Portuguese influence in Asia also limited the Castilian presence to the islands of Luzon and the Visayas in the Philippines, which were similarly threatened by powerful empires and neighboring sultanates. Whether it was in defining the relations between imperial polities, establishing commercial treaties, organizing imperial jurisdictions, or defining the ways in which inhabitants would be ruled, these geopolitical conditions created an intense need for regulation and provoked shifts in such rules as the balance of power changed over time.

Second, evangelization was a central element of the Iberian empires and, thus, with imperial expansion came the Catholic Church. The Padroado and the Patronato placed the crowns of Portugal and Castile, respectively, in charge of the administration of ecclesiastical affairs in their territories. Bishoprics and dioceses were created across Asia throughout the 16th and 17 th centuries, and spiritual centers were created with the elevation of Goa (1558) and Manila (1595) to archdioceses. With the Church also came the Inquisition. As such, the Inquisition was only established in Goa (1560), where it functioned until its final suppression in 1812. In the Philippines, the Inquisition was established in 1583, represented by a commissary but dependent on the Tribunal of the Holy Office in New Spain in Mexico City. The Philippine Inquisition was abolished in 1821, one year after the abolition of its Spanish counterpart. ${ }^{8}$ Additionally, since the Church had jurisdiction over all Christian communities in Asia, its influence was often territorially much vaster than that of the Iberian crowns. ${ }^{9}$ Missionaries frequently became "first conquerors', 'pioneers', of political expansion", 10 opening spaces that would later be incorporated into royal jurisdiction, and

7 Thomaz, De Ceuta a Timor, 3 o.

8 Angeles, "The Philippine Inquisition: A Survey"; Paiva, "The Inquisition Tribunal in Goa: Why and for What Purpose?".

9 Hespanha, Filhos da Terra: Identidades Mestiças nos Confins da Expansão Portuguesa, 205.

10 Xavier and Olival, "O Padroado da Coroa de Portugal: Fundamentos e Práticas", 147. 
also integrating populations that were otherwise never under direct control of the Iberian crowns. ${ }^{11}$ While Japan was perhaps the most emblematic case of this latter phenomenon, Portuguese and Spanish missionaries reached Persia, the Mughal Empire, Tibet, Bhutan and inland China. ${ }^{12}$ The presence of the Church in Asia was important for the generation of norms not only because it regulated important aspects of social and religious life both within and outside the jurisdiction of the Iberian empires, but also because it fostered dense networks of normative communication with important spiritual centers in Mexico City, Manila, Goa, and Macau — often beyond the influence of Rome, Lisbon, and Madrid. ${ }^{13}$

Third, while the Portuguese imperial network was reinforced in the western Indian Ocean, where the military and administrative focus of the Estado da Índia was placed, its expansion toward Southeast Asia and the Far East was carried out through a combination of formal and informal enterprises. The process of 'informal colonization', spurred by adventurers, renegades, merchants, missionaries, and pirates, who created "pockets of Portuguese across Asia from the Levant to China", ${ }^{14}$ created settlements that either were eventually formally integrated into the empire, as with Macau (founded in 1557 ), ${ }^{15}$ or led to communities of Portuguese that lived under foreign rule, as with Nagasaki (founded in 1570). ${ }^{16}$ The trade routes themselves came under imperial jurisdiction with the establishment of the nau do trato, an annual voyage that connected Goa with Japan via Macau, under the auspices of the Portuguese Crown and led by a Capitão-Mor. The Capitão-Mor not only enjoyed jurisdiction over the ships of the voyage but, until 1623, also acted as the interim Governor of Macau during

11 Subrahmanyam, The Portuguese Empire in Asia, 1500-1700, $262 \mathrm{ff}$.

12 Hespanha, "Uncommon Laws: Law in the Extreme Peripheries of an Early Modern Empire", 193; Details in: Brockey, Journey to the East: The Jesuit Mission to China, 1579-1724; Didier, Le Portugais au Tibet: Les Premières Relations Jésuits (1624-1635); Flannery, The Mission of the Portuguese Augustinians to Persia and Beyond (1602-1747); Menegon, Ancestors, Virgins, \& Friars: Christianity as a Local Religion in Late Imperial China.

This occurred through the circulation of casos de conciencia and opinions, as shown in the chapters by Luisa Coutinho, Rômulo Ehalt, and Marina Torres Trimállez in this volume (Chapters 6, 8, and 9), but also through the production of doctrinal treatises. On the latter, see Duve, Egío and Birr (eds.), The School of Salamanca: A Case of Global Knowledge Production.

Russell-Wood, "Patterns of Settlement in the Portuguese Empire", 178. For some detailed depictions of this process, see Disney, A History of Portugal and the Portuguese Empire: From Beginnings to 1807, vol. 2, chap. 21; Hespanha, Filhos da terra; Subrahmanyam, The Portuguese empire in Asia, 1500-1700, especially chap. 9.

16 Subrahmanyam, The Portuguese empire in Asia, 1500-1700, 110. 
his stay in port and had jurisdiction over the Portuguese community in Nagasaki. ${ }^{17}$ Here, one sees to what extent the empire was represented not only by territorial control, but also "by floating networks of maritime routes, where the seat of power could be the mobile deck of a military or trade vessel".18 The Spanish informal empire, for its part, was represented by more or less successful missions launched from Manila toward East Asia and Southeast Asia, ${ }^{19}$ and to the Mariana Islands (1668) and the Caroline Islands (1710) in the Pacific. ${ }^{20}$ The Iberian presence in Asia was thus not always marked by a guided process of 'empire-building' but also included tenuous and interstitial jurisdictions guided by disparate interests and governed by different centers of power.

The Iberian empires in Asia set in motion a profound process of normative production and change throughout the region, but the empires themselves were never monolithically in control of how this process unfolded. This volume thus proposes a look at the Iberian empires in Asia to think about norms beyond empire in a dual sense. First, it seeks to move the historiographical focus beyond empire to highlight the ways in which law-making and local normativities operated beyond colonial rule. Second, it suggests a focus on norms as a way of escaping the often too narrow concept of law and to highlight the manifold underlying assumptions, deep-seated convictions, and cultural paradigms that shaped the way people governed, worshiped, and organized collective life.

The remainder of this introductory chapter lays out the historiographical debates about empire and law that shape this discussion and suggests that legal-historical research has reached a point where it should move toward a decentered history of law. The contributions in this volume draw on cases from South India, China, Japan, and the Philippines to illustrate different ways of dealing with these historiographical challenges, shedding light on how the history of the Iberian empires in Asia can be revisited with a focus on the law-making power of local normativities.

There has been much discussion about whether the Iberian experience, in Asia and elsewhere, was an imperial experience at all. Anthony Pagden has

\footnotetext{
17 Boxer, The Great Ship from Amacon.

18 Hespanha, "Uncommon Laws", 189.

19 Martínez Shaw and Alfonso Mola, "The Philippine Islands: A Vital Crossroads during the First Globalization Period", $32 \mathrm{ff}$.

20 Coello de la Rosa, Jesuits at the Margins: Missions and Missionaries in the Marianas (1668-1769).
} 
noted that in Europe until the 17th century the word 'empire' was only used to denote the Holy Roman Empire or as an equivalent of the idea of sovereignty: "Neither the Spanish nor the Portuguese, nor even the French, ever spoke of 'empire' [as an extended and detached empire] and the British only began doing so consistently after the loss of America". ${ }^{21}$ During the process of territorial consolidation that began through the conquest of the Muslim lands of the Iberian peninsula, the ideas of 'kingdom' (reino) and 'Crown' (corona) became commonly used in Portugal and Spain, respectively, to designate the idea of a superior territorial and jurisdictional power. Though the notion of empire constituted a powerful idea that guided the overseas expansion, neither Spain nor Portugal ever officially designated their possessions as composing an empire. ${ }^{22}$ At the height of the 16th century, the image that Spain still cultivated for its European and overseas possessions was that of a composite monarchy-a kingdom that ruled over various kingdoms. ${ }^{23}$ António Manuel Hespanha has called attention to the titles of the Kings of Portugal and Spain to reveal the composite nature of their rule, encompassing claims to territorial dominion, immaterial jurisdiction, and vague geographical references-including an indefinite "etc." for "unlisted and virtual political jurisdictional claims". 24

While in Portugal the use of the idea of 'empire' became tied to nationalist and imperialist political discourses of the 19th and 2oth centuries, the historiographical use of 'Spanish empire', according to a recent survey, was only introduced by British historian J. H. Parry in the 196 os. $^{25}$ Since then, it has become increasingly common to speak of a Portuguese or a Spanish 'empire,' ${ }^{26}$

$21 \quad$ Pagden, "Afterword: from Empire to Federation", 259.

22 Cardim and Hespanha, "A Estrutura Territorial das duas Monarquia Ibéricas (Séculos XVI-XVIII)", 76 .

23 Elliott, "A Europe of Composite Monarchies"; Koenigsberger, "Monarchies and Parliaments in Early Modern Europe Dominium Regale or Dominium Politicum et Regale".

24 The official title of the Portuguese Kings, as provided by Hespanha, was as follows: "Pela Graça de Deus, Rei de Portugal e dos Algarves, d'Aquém e d'Além-Mar em África, Senhor da Guiné e da Conquista, Navegação e Comércio da Etiópia, Arábia, Pérsia e Índia, etc.”. The title of the Spanish Kings: "Pela Graça de Deus, Rei de Castela, de Leão, de Aragão, das Duas Sicílias, de Jerusalém, [de Portugal,] de Navarra, de Granada, de Toledo, de Valência, da Galiza, de Maiorca, de Sevilha, da Sardenha, de Córdova, da Córsega, de Múrcia, de Jáen, dos Algarves, de Algeciras, de Gibraltar, das Ilhas de Canária, das Índias Orientais e Ocidentais, Ilhas e Terra Firme do Mar-Oceano, Conde de Barcelona, Senhor da Biscaia e de Molina, Duque de Atenas e de Neopátria, Conde de Rossilhão e da Cerdanha, Marquês de Oristano e de Gociano, Arquiduque de Áustria, Duque da Borgonha, do Brabante e de Milão, Conde de Habsburgo, da Flandres e do Tirol, etc.". See Hespanha, "Uncommon Laws", 188.

25 Hausser and Pietschmann, "Empire: The Concept and its Problems in the Historiography on the Iberian Empires in the Early Modern Age", 11.

26 Disney, A History of Portugal and the Portuguese Empire; Flores, "The Iberian Empires, 1400 to 1800 "; Subrahmanyam, The Portuguese Empire in Asia, 1500-1700. 
though the ideas of 'expansion', 27 'monarchy', ${ }^{28}$ and 'world' ${ }^{29}$ are still used as alternatives. The more recent proliferation of the idea of empire has followed other historiographical trends of the past 30 years, particularly those related to the critique of methodological nationalism. To a certain extent, following the rise of Atlantic and global history, the concept of empire became a way to both broaden historical research beyond the borders of the nation state and construct new units of comparison. This has led to a multiplication of studies that explore the development of single empires, inter-imperial competition in a regional perspective, ${ }^{30}$ diachronic and synchronic comparisons between empires, ${ }^{31}$ and empires in their connections. ${ }^{32}$

Agreement on a concept of empire has, however, remained elusive. Being more of an analytical category than a historical one, linked to a more recent 'imperial turn', it is perhaps important to recall what the idea of empire is meant to convey. Of course, this is not a straightforward issue, since the concept is intended to make both diachronic and synchronic comparisons possible, thus integrating a temporally and geographically wide range of political formations. The question also poses issues of commensurability across cultures-a question posed by Jack Fairey and Brian P. Farrell: "are tianxia in Chinese, pādhsāhi in Persian, and samräjya in Sanskrit, for example, all interchangeable words for 'empire', or did they describe fundamentally different kinds of entities?". ${ }^{33}$ The issues of commensurability are not restricted to differences between, but also apply to differences within world regions; the Dutch, French, British, and other European empires were not exactly congruent political formations. ${ }^{34}$ Even despite their cultural affinities, Portugal and Castile constructed two quite distinct forms of empire, and the American often contrasted starkly with the Asian experience. ${ }^{35}$

27 Bethencourt and Curto (eds.), Portuguese Oceanic Expansion, 1400-180o; Boxer, Igreja Militante e a Expansão Ibérica 1440-1770; Hespanha, Filhos da terra.

28 Xavier, Palomo and Stumpf (eds.), Monarquias Ibéricas em Perspectiva Comparada (Séculos XVI-XVIII): Dinâmicas Imperiais e Circulação de Modelos Político-Administrativos.

29 Bouza, Cardim and Feros (eds.), The Iberian World: 1450-1820.

30 Brunero, Fairey and Farrell (eds.), Empire in Asia: A New Global History.

$31 \quad$ Alcock et al. (eds.), Empires: Perspectives from Archaeology and History; Burbank and Cooper, Empires in World History: Power and the Politics of Difference.

$3^{2}$ Subrahmanyam, Empires between Islam and Christianity, 1500-1800.

33 Fairey and Farrell, "Reordering an Imperial Modern Asia", 4.

34 Pagden, "Afterword: From Empire to Federation".

35 Biedermann, The Portuguese in Sri Lanka and South India: Studies in the History of Diplomacy, Empire and Trade, 1500-1650, 34; Subrahmanyam, Empires between Islam and Christianity, 1500-1800, 6-7. 
Despite these difficulties, it may be possible to combine the diverse definitions of empire into two groups: a metropolitan and a cosmopolitan image of empire. The metropolitan image of empire hinges on the idea of a center that is capable of subordinating the territories under its rule. This idea is based on the experience of what Pagden has called the 'second European empires', typical of the colonial projects of the mid-19th and 2oth centuries and ideologically shaped more by nationalism than by Roman universalism. ${ }^{36}$ Empire, in this image, is primarily defined through distinctions between center and periphery or metropole and colony, and is characterized by the center's capacity to unilaterally impose political, economic, and cultural control over its periphery. ${ }^{37}$ This is, for example, the implicit view observed in much of the literature reviewed by Christian Hausser and Horst Pietschmann: "the latest works continue to be based above all on the most recent conjuncture of 'empire' and as such follow the same lines as the usual fuzzy concepts - a political structure of immense scale, often transcontinental, oriented politically, economically and also in part culturally toward a centre that itself radiates towards the periphery". ${ }^{38}$ The center in this notion of empire tends to be equated with Europe and has not only been used to describe the imperial experiences of the 19th and 2oth centuries, but has also been transposed to the early modern period, particularly in international law scholarship. ${ }^{39}$

In the cosmopolitan image, by contrast, empire is understood as a form of political rule defined by expansive and expansionist territorial dominion, often achieved through conquest, by composite and layered distribution of political power, and by higher or lower tolerance of ethnic, cultural, and religious diversity. ${ }^{40}$ This image of empire has been used to include a wide range of imperial experiences from all over the world and from antiquity until the early 19th century. Underlying this view is often-though not always-a con-

36 Pagden, Lords of All the World: Ideologies of Empire in Spain, Britain and France c. 1500c.180o, 9 .

37 Subrahmanyam, Empires between Islam and Christianity, 1500-1800, 6.

38 Hausser and Pietschmann, "Empire", 7.

39 See, for example, Halperin and Palan, "Introduction: Legacies of Empire", 10; Also: Maier, Among Empires: American Ascendancy and Its Predecessors; Roper and Van Ruymbeke (eds.), Constructing Early Modern Empires: Proprietary Ventures in the Atlantic World, 1500-1750.

40 Cooper, Colonialism in Question: Theory, Knowledge, History, chap. 6; Fairey and Farrell, "Reordering an Imperial Modern Asia", 5; Howe, Empire: A Very Short Introduction, 3o; Kumar, Visions of Empire: How Five Imperial Regimes Shaped the World; Subrahmanyam, "Written on Water: Designs and Dynamics in the Portuguese Estado da Índia", 2001, reprint 2005, 43; Wendehorst (ed.), Die Anatomie frühneuzeitlicher Imperien: Herrschaftsmanagement jenseits von Staat und Nation Institutionen, Personal und Techniken. 
trast with the homogenizing tendencies of the nation-state, emphasizing the plural and differentiated distribution of power that characterized the political forms before the 19th century. Jane Burbank and Frederick Cooper have synthesized this point as follows: "The concept of empire presumes that different peoples within the polity will be governed differently" ${ }^{41}$ Unlike the metropolitan perspective, which focuses on the influences of the center on its periphery, this approach highlights the internal diversity and fluidity of the imperial system and thus allows for a plural—but not for this reason less violent-articulation between the different regions, networks, and interests that composed the imperial space. The cosmopolitan and the metropolitan images, thus, share the idea of asymmetrical integration and the use of violence and force as means for political control.

This distinction between the metropolitan and the cosmopolitan images are meant to convey how historians tend to think, either explicitly or implicitly, about the problem of empire. While the former understands empire in terms of centralization and standardization, the latter focuses on its internal complexity, the fluidity of its territories and composite parts, and the general flexibility it had as a form of political rule. In a way, one could argue that the cosmopolitan image was meant to provide an alternative to the metropolitan view as a growing variety of political models, world regions, and historical periods have been included in the historiography of empire. As Sanjay Subrahmanyam has noted, the issue at the heart of this has been, "namely, that various sorts of imperial polities have existed in the past, which do not all conform to a single profile, with a contiguous landmass, centralized fiscal and cadastral organizations, and powerful and continuous military presence in peripheries that are rigorously controlled from a well-defined center". ${ }^{42}$ Zoltán Biedermann has, perhaps, framed it most eloquently by arguing that, in political models characterized by complexity and uncertainty, "it is crucial that we allow the words 'empire' and 'imperial' sufficient space to breathe".43

Even though these differing concepts of empire present quite divergent images of how rule was organized, within this literature law has often been restricted to a metropolitan image. The relative consistency of legal systems throughout the contemporary world is often seen as the outcome of a process though which European law was imposed on the non-European world through imperialism. This view was synthesized in Wolfgang J. Mommsen's introduction to the volume European Expansion and Law, published in 1992:

\footnotetext{
41 Burbank and Cooper, Empires in World History, 8.

42 Subrahmanyam, "Written on Water", 44.

43 Biedermann, The Portuguese in Sri Lanka and South India, 34.
} 
There is no doubt that during the period of European expansion the introduction of Western principles of law, although through the back door of special colonial law designed originally to maintain colonial control, had a lasting impact upon the societies in the non-Western world, and still continues to do so, which in hindsight may be judged at least in part as beneficial. ${ }^{44}$

In the same volume, Jörg Fisch argued that this outcome was not in all cases an intended effect of empire. European law moved across the world, sometimes, as a concomitant effect of migration and, other times, as an explicit instrument of rule. Ultimately, according to this view, "law was certainly not only a stabilizing factor for European rule but also an important agent for extending it, whether in the political or in the economic field". ${ }^{45}$ Europe was thus placed at the center of empire, and law was seen as radiating, in diverse manners, toward a non-European world that was conceived as a periphery.

This volume was seminal in its focus on the relationship between law and empire and anticipated the formation of a field that, since the 20oos, has rapidly grown in significance. ${ }^{46}$ This emerging field has expanded research to include postcolonial perspectives while attempting to move the focus of law from the center of empire toward its peripheries. ${ }^{47}$ Unlike the characterization presented above, the more recent historiography of law and empire tends to take a more critical view of European law. ${ }^{48}$ Antony Anghie, for example, has pointed to the colonial origins of international law and shown how the violence and discrimination inherent to its 'civilizing mission' continues to pervade international law until today. ${ }^{49}$ Lauren Benton's work has taken the 'colonial origins' perspective in a different direction, detaching international law from its supposedly European origin and making it the result of an "ordered and contested multiculturalism"50 that played out in the practice of solving conflicts across different local scenarios. ${ }^{51}$ Other recent ways of understanding the

\footnotetext{
44 Mommsen, "Introduction", 13.

45 Fisch, "Law as a Means and as an End: Some Remarks on the Function of European and Non-European Law in the Process of European Expansion", 33.

46 Benton, "AHR Forum: Law and Empire in Global Perspective: Introduction", 1092.

47 Especially: Anghie, Imperialism, Sovereignty, and the Making of International Law; Benton, Law and Colonial Cultures: Legal Regimes in World History, 1400-1900; Benton, A Search for Sovereignty: Law and Geography in European Empires, 1400-1900.

48 Among others: Koskenniemi, Rech and Jiménez Fonseca (eds.), International Law and Empire: Historical Explorations; Pitts, Boundaries of the International: Law and Empire.

49 Anghie, Imperialism, Sovereignty, and the Making of International Law.

50 Benton, Law and Colonial Cultures, 7.

51 A good overview can be found in: Benton, "Made in Empire: Finding the History of International Law in Imperial Locations".
} 
relation between law and empire can also be found in the connections established between imperial history and legal pluralism: "pluralistic legal structures were the norm [...] inside empires, both in spaces considered homeland $[\ldots]$ as well as in more distant regions into which empires expanded".52

The idea of law in this more recent literature is, however, still tied to a metropolitan image of empire. First, despite its more critical view, the literature of international law views international law, but also increasingly private law, as an instrument of empire. ${ }^{53}$ Second, in a related manner, it shares with Mommsen and Fisch the idea that law is a European cultural achievement that was diffused to the non-Western world through violence and coercion in the process of colonization. The focus on certain treatises and authors (Grotius, Vitoria, Vattel, to name a few) tends to place the creation and development of law in Europe - even if it was shaped through the colonial experience. ${ }^{54}$ Third, though legal pluralism is recognized as a basic feature of law in empire, the assumption is that this is the case because it was allowed by power holders. Legal pluralism is thus simply seen as another way in which the metropolis governed. Finally, though Benton's displacement of law-making from the metropolis to the periphery is certainly an important methodological step in the right direction, the interest still remains more prevalent in empire than in law. On the one hand, this is due to a narrow concept of law, reduced to the way in which law is mobilized in 'political' conflict and struggle. Thomas Duve has labeled this approach "a history of colonial laws of empires". ${ }^{55}$ On the other hand, the focus on 'legal practice' explicitly requires historians to ignore norms and the "normative structures' operating in deep background to legal behavior and utterances" 56 while, at the same time, restricting legal behavior to courts and other formal instances of legal decision-making. ${ }^{57}$

$5^{2} \quad$ Burbank and Cooper, "Rules of Law, Politics of Empire", 281; Also, more generally: Benton and Ross (eds.), Legal Pluralism and Empires, 1500-1850; Duindam et al. (eds.), Law and Empire: Ideas, Practices, Actors; For a good overview of this in the context of Central Europe, see: Härter, "Das heilige römische Reich deutscher Nation als mehrschichtiges

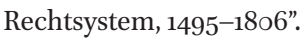

53 Koskenniemi, "Introduction: International Law and Empire: Aspects and Approaches".

54 For an interesting example of a different approach, including the literature therein cited, see: Weststeijn, "Provincializing Grotius: International Law and Empire in a Seventeenth-Century Malay Mirror".

55 Duve, "What is Global Legal History?", 30.

56 Benton, "In Defense of Ignorance: Frameworks for Legal Politics in the Atlantic World", 280. Two critical comments of this approach can be found in: Duve, "What is Global Legal History?"; Herzog, "What Natives Said and How Europeans Responded in Late-Seventeenthand Eighteenth-Century Portuguese America", in Owensby; Ross, Justice in a New World.

57 Especially, Benton, "The Legal Regime of the South Atlantic World, 1400-1750: Jurisdictional Complexity as Institutional Order". 
The idea of law that dominated the Iberian worldview was nevertheless broader than an 'imperial' image may suggest. Law was a pervasive presence. Thought to derive from God, it had a quasi-ontological quality and was understood as an ordering force that could be found both in nature and in all kinds of human institutions and practices. ${ }^{58}$ Animals, for example, were thought to have legal capacities - in substance equal or analogous to those of humansand stood in legal relationships with each other and with other things. Thus, lands, animals, and things could be 'punished' or enjoy rights and privileges. ${ }^{59}$ Colors equally conveyed legal meanings and were to be worn on certain parts of the body or were reserved to specific dignitaries. ${ }^{60}$ And within the human realm, etiquette, manners, rituals, ceremonies, and all kinds of behaviors were considered to convey legal meaning and, if improperly performed, could lead to injury and liability. Social relationships were linked to emotions and affections and were, accordingly, performed and reinforced through external manifestations: "To bow or to stand, to kiss the hands or the face, to take off the hat or to put it on were corporal dispositions from which one could infer corresponding internal dispositions" ${ }^{61}$ Honor, duty, obedience, freedom, and faith were not only meant to be important ideals, but also had to be publicly performed and seen. ${ }^{62}$ This "pan-juridification of the world", as Hespanha has called it, meant that law acted more as a cultural paradigm, "so deeply rooted that it extend[ed] over a wide set of normative discourses, like moral theology, ethics, economy $[\ldots]$ and politics". ${ }^{63}$

This juridical worldview has been reconstructed in the past three decades by Spanish, Portuguese, and Italian legal historians, who have tried to move away from legalist and statist conceptions of contemporary law to rediscover the alterity of the ancien régime by drawing on its peculiar anthropology. ${ }^{64}$ In this

$5^{8}$ Grossi, El Orden Jurídico Medieval.

59 Girgen, "The Historical and Contemporary Prosecution and Punishment of Animals"; Humphrey, "Bugs and Beasts before the Law".

6o Hespanha, "As Cores e a Institução da Ordem no Mundo de Antigo Regime".

61 Hespanha, "Early Modern Law and the Anthropological Imagination of Old European Culture", 196.

62 To understand how this is embodied and practiced by the magistrate, see: Vallejo, "Acerca del Fruto del Árbol de los Jueces: Escenarios de la Justicia en la Cultura del Ius Commune".

63 Hespanha, "Early Modern Law and the Anthropological Imagination of Old European Culture", 201.

64 Clavero, Tantas Personas como Estados: Por una Antropología Política de la Historia Europea; Clavero, Antídora: Antropología Católica de la Economía Moderna; Grossi, El Orden Jurídico Medieval; Hespanha, Como os Juristas viam o Mundo. 1550-1750: Direitos, Estados, 
worldview, law was guided by two underlying principles that fundamentally differ from what we understand as its central underpinnings today. First, in this normative order, law was understood to derive not from the state or political power, but from divine creation and, as such, preceded and transcended human intervention. This helps explain the pervasive view of law: God created order from chaos and gave its place to everything that was in the world, and thus humans, animals, and things, and the relations between and among them, were governed in substance by the same rules. This was a holistic conception in which law was not considered to be substantively different from natural and social reality itself.

Second, human existence was not understood as oriented toward the unfolding of the individual but was rather tied to the ontological and juridical primacy of the community and the corporative organization of society. Society was composed of corporate bodies (corpora) of diverse natures, organized around profession, trade, or territorial adscription, each of which had a different legal status and possessed great autonomy and capacity for self-regulation. ${ }^{65}$ Guilds, parishes, villages, cities, universities, dioceses, religious orders, and the kingdom are some examples of these corporations. ${ }^{66}$ These ideas can be considered the 'deep background to legal behavior and utterances', which was so obvious to early modern Iberian imagination that legal historians have had to parse through the "surface of the text" to reveal the worldview "encrypted behind the discourse, composed of convictions that were so fundamental that they did not need to be explicitly uttered for whomever was immersed in that 'other' society". ${ }^{67}$

The capacity to transform the divine, natural order into human law was at the root of the ancien régime's conception of political power and was encompassed under the concept of iurisdictio, as the power to 'declare the law' and

Pessoas, Coisas, Contratos, Ações e Crimes; Hespanha, La Gracia del Derecho: Economía de la Cultura en la Edad Moderna; Hespanha, Visperas del Leviatán: Instituciones y Poder Político; Petit, Pasiones del Jurista: Amor, Memoria, Melancolía, Imaginación.

65 Bastias Saavedra, "Jurisdictional Autonomy and the Autonomy of Law: End of Empire and the Functional Differentiation of Law in 19th-Century Latin America".

66 Agüero, "Las Categorías Básicas de la Cultura Jurisdiccional", 27; Hespanha, História das Instituições: Épocas Medieval E Moderna, chap. 6.

67 Agüero, "Las Categorías Básicas de la Cultura Jurisdiccional", 23. Of course, beyond these ontological foundations, almost every aspect of law was riddled with implicit background assumptions such as, for example, the virtues and qualities-nobility, wisdom, experience, prudence, patience, humility, eloquence, to name a few—a judge had to possess to pass just judgements. These virtues and qualities in turn were also grounded in underlying norms. On this, see: Vallejo, "Acerca del Fruto del Árbol de los Jueces". 
'establish fairness' (aequitas). ${ }^{68}$ As such, human law-making was always a process of declaring or revealing — but not creating — the law already handed down by the divine order. ${ }^{69}$ This conception tied the legitimate exercise of power to the theological notion of justice, thus subordinating political power to the original normative order and making every act of authority an expression of that order. In this judicial model of government, the power to rule was inseparable from the power to judge. ${ }^{70}$

This manner of conceiving political power was also coherent with the corporative structure of society in which diverse holders of jurisdiction operated simultaneously and exercised varying magnitudes of power over partially or totally coinciding territories or groups of persons. ${ }^{71}$ The holder of jurisdiction, as the head of the social body, was understood to exercise the aptitude of self-government that was inherent to every human community. ${ }^{72}$ And insofar as the legitimacy of the exercise of jurisdictional power within each corporation arose from within itself, each sphere of jurisdiction was considered to have an autonomous — not delegated—origin. ${ }^{73}$ It may be important to note that this corporate structure meant that jurisdiction was not only limited to the state and the Church; jurisdiction was widely distributed across all corporate bodies outside of the family which, though being the most basic and perfect corporation, was not a space governed by justice. ${ }^{74}$

The law-making capacities of political power were thus subordinated to a transcendent order, on the one hand, and to the corporate structure of traditional society, on the other, both acting as ontological premises that served as structural limitations to the 'centralization' of power. ${ }^{75}$ The Monarch could not dispose of the law at will but could only act so as to sustain the natural order through justice or perfect it by grace. ${ }^{76}$ But the power of the Crown was also limited by the jurisdictional structure of government which, although

68 Hespanha, Como os Juristas viam o Mundo. 1550-1750, 35. For a more detailed analysis, see: Costa, Iurisdictio: Semantica del Potere Politico nella Pubblicistica Medievale (1100-1433); Vallejo, Ruda Equidad, Ley Consumada: Concepción de la Potestad Normativa, (1250-1350).

69 For an insightful essay on the transformative power of law-making, see: Vallejo, "El Cáliz de Plata: Articulación de Órdenes Jurídicos en la Jurisprudencia del Ius Commune”.

Agüero, "Las Categorías Básicas de la Cultura Jurisdiccional", 31; Garriga, "Orden Jurídico y Poder Político en el Antiguo Régimen", 18. Vallejo, "Power Hierarchies in Medieval Juridical Thought: An Essay in Reinterpretation", 3.

72 Grossi, El Orden Jurídico Medieval, 67.

73 Vallejo, "El Cáliz de Plata", 11.

74 Zamora, Casa Poblada y Buen Gobierno: "Oeconomía” Católica y Servicio Personal en San Miguel de Tucumán, Siglo XVIII.

75 Garriga, "Orden jurídico y Poder Político en el Antiguo Régimen”, 8.

76 Hespanha, Como os Juristas viam o Mundo. 1550-1750, 66. 
organized through relations of super- and subordination, precluded a unitary and hierarchical integration of political power. ${ }^{77}$ This premise has been used to show how the increasing importance of monarchical power after the $15^{\text {th }}$ century, rather than expanding the executive functions of the Prince, produced a progressive specialization in the exercise of jurisdiction. ${ }^{78}$ The consolidation of the early modern monarchies thus occurred through the development of a dual jurisdictional order: that of the king and his judge-administrators and that of the traditional corporative social structure. ${ }^{79}$ As such, "the corporative society grows and develops alongside the modern monarchy, in a tight bond that will only be dissolved with the advent of the liberal State". 80 These features of the relation between law and political power in the Iberian monarchies were shared with other early modern monarchies and empires. ${ }^{81}$

Law-making was not only limited to the holders of jurisdiction, but was also a capacity of jurists and theologians, whose prestige, authority (auctoritas), and knowledge of the textual tradition made them important sources of normativity. Though they were not vested with iurisdictio, and thus could not declare the law in the same sense as a holder of jurisdiction, the jurist (in canon or civil law) and, beginning in the 16th century, the moral theologian shared the hermeneutical capacity to transform the divine order into law through interpretatio. Law-making was, by definition, interpretative, and there was therefore no substantive difference in the interpretatio of the Prince, of the community through its customs, of the judge in the administration of justice, or as the conceptual construction of the jurist and the theologian. ${ }^{82}$ The difference, however, was that the interpretatio of the scholars was not general nor necessary, only probable - the binding force of their opinions was authoritative and persuasive, showing ways to find the right solutions without providing the solutions as such. ${ }^{83}$ But this scholarly law was not merely theoretical or confined to books and universities; it also found different forms of practical use, either through the condensation of this knowledge into pragmatic literature

\footnotetext{
77 Vallejo, "El Cáliz de Plata", 8.

78 Mannori, “Justicia y Administración entre Antiguo y Nuevo Régimen”, 132.

79 Hespanha, "Centro e Periferia nas Estruturas Administrativas do Antigo Regime", 55.

8o Agüero, Castigar y Perdonar Cuando Conviene a la República: La Justicia Penal de Córdoba del Tucuman, Siglos XVII y XVIII, 36-37.

81 Härter, "Das heilige Römische Reich deutscher Nation als mehrschichtiges Rechtsystem, 1495-1806", 345-346.

82 Grossi, El Orden Jurídico Medieval, $168 \mathrm{ff}$.

83 On how textual and practical knowledge was involved in producing these norms, see: Duve, "Pragmatic Normative Literature and the Production of Normative Knowledge in the Early Modern Iberian Empires (16th-17th Centuries)", 12.
} 
for practitioners or through the opinions produced by jurists and theologians to solve specific issues that arose in different contexts. ${ }^{84}$ The jurist/theologian thus mediated between the realms of concepts and facts, meaning that interpretatio had a creative function in the sense that it could modify the formal reservoir of normative knowledge - the legal doctrine of the ius commune and canon law, Scripture, and the 'ancient wisdom' taken from the authors of classical antiquity - to create new norms that reflected existing and new states of affairs. ${ }^{85}$

Two important preliminary conclusions for understanding the relation between law and empire can be drawn from this new legal historiography. First, it stresses the impossibility of conceiving of a centralized political power. Political power, insofar as it was based on iurisdictio, was widely fragmented and, though organized in higher- and lower-orders of power, excluded the possibility of a unitary political structure. The idea of governing by difference, stressed by the more recent imperial history, was a feature of such a political system, not only because it was efficient, but also because it is the way in which the exercise of political power was fundamentally conceived. Second, following this logic, law-making was not a monopoly of the ruler but was a capacity that was also widely fragmented and distributed. However, in a strict sense, it is a mistake to conceive this law in terms of legal pluralism because it was, in fact, a unitary order based on hierarchies, inequalities, and difference-which, as we have seen, encompassed the natural and supernatural world created by God - and it thus tended toward plurality rather than uniformity. Accordingly, law could manifest itself in many forms - in principle, in as many concurrent forms as there were corpora. ${ }^{86}$ It is therefore perhaps better to speak of multinormativity with the understanding that human behavior was (and is) ordered by different techniques of both formal and informal regulation ${ }^{87}$-ranging from the implicit and deep-seated convictions about the world and the

84 On the former, see the articles in: Duve and Danwerth (eds.), Knowledge of the Pragmatici: Legal and Moral Theological Literature and the Formation of Early Modern Ibero-America. On the latter, see chapters 6,8 , and 9 in this volume.

85 Grossi, El Orden Jurídico Medieval, 174.

86 Donlan and Heirbaut (eds.), The Law's Many Bodies: Studies in Legal Hybridity and Jurisdictional Complexity, C. 1600-1900.

87 Duve, "Was ist Multinormativität? Einführende Bemerkungen". The idea of multinormativity may even include what Christopher Tomlins has called 'legality', understood as "a condition with social and cultural existence" produced not only in formal settings but "generated in the course of virtually any repetitive practice of wide acceptance within a specific locale, call the result rule, custom, folkway or pastime, popular belief or protest". Tomlins, "The Many Legalities of Colonization: A Manifesto of Destiny for Early American Legal History", 2-3. 
cultural conventions outlined at the beginning of this section to aesthetic and linguistic standards, customs, royal edicts, and legal doctrine, including even the regulation of time and the life cycle, as discussed by Fupeng Li (Chapter 10) in this volume.

This basic model of law and government accompanied the Portuguese and Castilian crowns as they extended their rule to other parts of the Iberian Peninsula, as well as to Africa, Asia, and the Americas. ${ }^{88}$ The Castilian system of Audiencias and Chancillerías, developed in the 14th and 15th centuries to represent the person of the king and guarantee the juridical order of the kingdom, was consolidated and perfected in America and the Philippines from the 16th century. Insofar as they stood in for the king-speaking with his voice and occupying his place in the definition of justice-the Audiencias were fundamental in defining the configuration of the political space of the Crown. They were also the way in which the military power of the conquistadors was tempered through the civil power of the king's magistrates. However, neither the Audiencias nor the other offices established for the government of the Indies should be understood as executive or administrative arms of the metropolis, but rather as jurisdictional bodies: i.e., performing, at once and without clear distinctions between them, the functions of government and justice. These magistrates and officers of the Crown, insofar as they enjoyed jurisdiction, were authorized by, and even protected against, royal orders, ${ }^{89}$ and thus acted at the same time as "instruments of and obstacles to royal policy". ${ }^{90}$ The royal institutions of the Portuguese monarchy functioned essentially under the same logic. ${ }^{91}$

The jurisdictional logic, however, was not only deployed by royal institutions, but was also replicated through the corporate structure of society, tied to the corporations that accompanied the expansion of the Iberian empiresthe Church, the Inquisition, brotherhoods, religious orders, cabilidos and cámaras, guilds, cities, provinces, etc. - and to the corporations that organized local rule-pueblos, gaunkaris, and barangays, to name a few. ${ }^{92}$ These corporations sometimes acquired explicit privileges granted by the monarch, such

88 Cardim and Hespanha, "A Estrutura Territorial das duas Monarquia Ibéricas (Séculos XVIXVIII)".

89 Hespanha, "Antigo Regime nos Trópicos? Um Debate sobre o Modelo Político do Império Colonial Português", 46.

90 This section follows: Garriga, "Las Audiencias: Justicia a Gobierno de las Indias", 724. Emphasis in the original.

91 Hespanha, Visperas del Leviatán: Instituciones y Poder Político, chap. 5 .

92 On the gaunkaris and the barangays, respectively, see Xavier and Perez (Chapters 2 and 3 ) in this volume. 
as the forais, but also developed their own local, unwritten norms based on longstanding practices and conventions. ${ }^{93}$ The principle underlying this was that every community was endowed with an inherent capacity for self-government. Importantly, neither the laws of the king nor those of other instances of general law-making - e.g., the Church-could supersede or contravene the law and the law-making capacities of these corporations. In this conception, the "centrality of law was translated, in fact, to the centrality of local normative powers, both formal or informal, of the uses of the land, of 'rooted' situations (iura radicata), in the attention to the particularities of the case". ${ }^{94}$ Outside of the king's jurisdiction, relations with foreigners and foreign rulers, with allied potentates through amistad (friendship), and with enemies were also regulated by the ius gentium, creating different sets of norms that, though beyond the power of the monarch, were not foreign to the unitary framework of the juridical order of the ancien régime.

The law of empire, therefore, rather than creating the conditions for voluntary, central rule, supported and reinforced the dispersion of and limitations to law and political power:

Empire's law was a chaotic compound of legal regimes, combining the diversity of the very Metropolitan law with a wide array of particular legal orders, local usages and judicial styles. [...] Rather than representing a hierarchical legal order dominated by a common set of imperial prescriptions, imperial law was a lacing machinery knotting legal threads of different colors and resistance, assisted by a disperse and incoherent body of officers, applied with the most diverse intensity to diversely dependent subjects. ${ }^{95}$

The localism and contextualization of law thus endowed the countless local situations of the empire with a political and juridical autonomy that precluded a pervasive rule and determination from the metropolitan center.

Therefore, in the case of the Iberian empires, if one can speak of the transference of a metropolitan model to the colonies at all it was in the way the ancien régime logic of law and government of the Peninsula was replicated under new conditions. The outcome of this process was not the transposition of European law to the non-European world but a 'normative overload', as the needs of imperial government required the creation of new norms through the

93 Hespanha, “Antigo Regime nos Trópicos?", 55.

94 Hespanha, "Depois do Leviathan", 57.

95 Hespanha, "Uncommon Laws", 186. 
adjustment to local forms of social and political reproduction. This normative overload was a consequence of the logic of norm-production in the early modern world, in which new norms did not derogate older ones, thus leading to an ever-growing accumulation of normative information. And this information grew exponentially as the Iberian empires extended their rule. In each new place, kings enacted decrees and bestowed privileges; officials handed down rules; jurists, clerics, and theologians — not only in Salamanca and Rome, but also in Goa, Mexico City, Lima and Manila-drew on bodies of law, authorities, and classics to produce normative solutions for new situations; magistrates had to reach judgements; and cities, villages, and other territorial communities created or sustained their own norms and customs. Both before and after the 15th century, the existence of contradictory norms was the rule. The solution to navigating this normative complexity was simple: learning the facts inductively, respecting the particularities of the case, and aiming to sustain the interests of each party as they were understood to be-justice could only ever be local and particular, regardless of its place within the political structure of the empire.

\section{Norms beyond Empire: Decentering the History of Law}

The insights of this recent 'imperial turn' in legal historical research provide both an invitation and a challenge. On the one hand, they form an invitation to explore the complexities of local norm-production, giving it the central position that it had in the early modern period. On the other hand, they form a challenge insofar as this historiography leaves us with incomplete tools and concepts to take the next step: namely, how to analyze and interpret the ways in which vernacular normative orders and non-European and non-Christian local practices helped shape and order life in the Iberian empires. Despite the nuance and complexity it offers, the doctrinal corpus of the ius commune, which has helped legal historians understand the alterity of the European ancien régime, is still a blunt instrument for understanding what happened once the Iberian world moved beyond the Atlantic and the Mediterranean. Legal history is no longer simply confronted with the otherness of the early modern mentality, but is now also challenged with understanding and finding ways to integrate the different traditions, pasts, and histories of the peoples that, in one way or another, encountered and suffered under the Iberian empires.

These are the challenges faced by a legal history that is no longer European but global, and addressing them requires constructing appropriate conceptual 
and methodological frameworks. ${ }^{96}$ Conceptually, the focus of legal history moves toward the idea of normativity. This serves to move legal history away from the often Eurocentric and narrow concept of law toward the less culturally charged idea of normativity, which highlights different orders of norms, their interactions, and their internal dynamics. ${ }^{97}$ Further, since norms are never straightforward, but rather respond to different kinds of expectations, interact in variegated manners, and are layered upon each other, normativity should always be understood as multinormativity. This draws particular attention to the manifold underlying rules, assumptions, and conditions of possibility for the production of norms. ${ }^{98}$ Tamar Herzog probably had a similar idea in mind when analyzing the interactions between the Portuguese and natives of the Brazilian interior: "I argue that beyond what was said and done, silently operating in the background were rules that linked speech and action to certain consequences. These rules anchored in culture and experience, were legal in the sense that they were normative. They prescribed which actions could be taken, which words could be pronounced, and what their results might be". ${ }^{99}$

Methodologically, the frame of reference is also not Europe, nor the connections between Europe and other world regions, but global. ${ }^{100}$ However, this does not mean taking a macro perspective, but in fact demands the prioritization of the local. This is not only because a local perspective is consequent with the logic of law-making of the ius commune culture, as outlined above, but also because it is the only way to access the variation, selection, and transformation of normative options: "only by observing the smallest units can the processes of law-making be reconstructed, only from this vantage point can regional or global connections be accessed". ${ }^{101}$ The focus on the local also means giving preference to local practices. ${ }^{102}$ Because norms were not only produced by

96 Duve, "Von der Europäischen Rechtsgeschichte zu einer Rechtsgeschichte Europas in globalhistorischer Perspektive".

97 Other legal historians have proposed solving this problem, rather, by avoiding having an a piori concept of law. See: Garriga, “¿De qué Hablamos los Historiadores del Derecho cuando Hablamos de Derecho?"; Hespanha, "Is there a Place for a Separated Legal History? A Broad Review of Recent Developments on Legal Historiography".

98 Duve, "Was ist Multinormativität?", $92 \mathrm{ff}$.

99 Herzog, "What Natives Said and How Europeans Responded in Late-Seventeenth- and Eighteenth-Century Portuguese America", 62.

100 Duve, "What is Global Legal History?”; Duve, "Global Legal History a Methodological Approach".

101 Duve, "Von der Europäischen Rechtsgeschichte zu einer Rechtsgeschichte Europas in globalhistorischer Perspektive", 49.

102 Duve, "Von der Europäischen Rechtsgeschichte zu einer Rechtsgeschichte Europas in globalhistorischer Perspektive", 51 . 
rulers, scholars, and courts, and because they were not only experienced by people as litigants, but were also lived, embodied, expressed as convictions, and practiced, the production and reproduction of normativity can only be read through sources that shed light on these cultural and social practices.

All of this points to decentering the history of law in both an epistemological and methodological sense. This perspective means that each case study becomes its own center from which meanings and connections are drawn and reconstructed. Each place, as its own center, reveals the ways in which it interacts with the wider world - and these interactions are unique. Instead of leading to a fragmentation of local case studies, it opens the possibility of understanding how law was simultaneously and globally co-constructed through the loose interaction of the "fragile threads"103 that connected different normative systems over the last five centuries. This draws inspiration from Subrahmanyam's appeal to delink certain global shifts from a supposedly European trajectory and agency, stressing that they actually have "many different sources and roots, and - inevitably - many different forms and meanings depending on which society we look at it from". ${ }^{104}$ The "structural similarities"105 and the "quasi-commensurability" 106 between the Iberian juridical worldview and that of the people submitted to their rule in Africa, Asia, Europe, and the Americas allowed for the interweaving of normative traditions that ultimately resulted in new configurations that were both no longer European and no longer native.

The chapters in this volume illustrate this approach by showing how local normativities were central to law-making in early modern Iberian Asia. First, this means integrating into the analysis different normative textual traditions, beyond imperial laws and the ius commune, and interrogating the ways in which these traditions interacted. Ângela Barreto Xavier (Chapter 2) reflects on the ways in which Dharmaśāstra, Smrti, and other Brahmanical treatises may have influenced the customs of Goan villages before the arrival of the Portuguese and how they were integrated into the nascent Portuguese imperial order, especially in rules concerning inheritance and land sales. Luisa Stella de Oliveira Coutinho Silva (Chapter 6) similarly discusses how marriage practices in 16th-century Japan can be seen from the vantage point of the missionaries' conceptions of canonical marriage, as well as from the perspective of

103 Subrahmanyam, "Connected Histories: Notes towards a Reconfiguration of Early Modern Eurasia", 762 .

104 Subrahmanyam, "Connected Histories", 737.

105 Benton, "The Legal Regime of the South Atlantic World, 1400-1750", 48.

106 Biedermann, The Portuguese in Sri Lanka and South India, 35. 
a long tradition of Japanese norms that regulated families and households, from those codified in the Ritsuryo in the 7th century to the House Laws of the Sengoku period. The construction of Christian marriage practices in Japan in the 16th century necessarily drew from these different textual traditions. Li (Chapter 10) seeks to redefine the imperial calendars in the late Ming and early Qing dynasties as "manuals of rituals" that combined and incorporated both Chinese and European knowledge. The calendars combined the astronomical knowledge of the Jesuits, traditional Chinese numerology, and Confucian and Taoist philosophy to construct a ritual order that synthesized multiple orders: the natural order, the order of the empire, and the organization of everyday life.

Second, local practices and institutions should be highlighted to better understand how colonial rule and Christianity were anchored in the long-term persistence of local normativities. Marya Svetlana T. Camacho (Chapter 5) provides an excellent example of this, showing how the Bisayan bugay and the Tagalog bigay-kaya remained central institutions in marriage between natives in the Philippines even after conversion. The chapter argues that even though Spanish sources tended to speak of dote (dowry) and religious authorities tried to adjust local marriage practices to Church precepts, natives actually 'localized' Christian marriage in the Philippines by sustaining the practice of bugay/ bigay-kaya throughout the centuries. Xavier (Chapter 2) also draws attention to the "several layers of experience" that constituted the multinormative Portuguese imperial order in Goa, based on administrative institutions of the Bijapur Sultanate, the local government of the gaunkaris, norms drawn from Brahmanical scholarship, and the efforts to consolidate the primacy of Portuguese law and Christian precepts. Abisai Perez Zamarripa (Chapter 3) also draws attention to the "indigenous jurisdiction hidden beneath Spanish rule", showing how colonial governance in the Philippines was built upon a layer of local normativities through the integration of repurposed pre-Hispanic institutions (barangays and datus) and customs. These examples point to the existence of 'subaltern normativities' that lived alongside and fed into the rule-making and institution-building processes of Iberian colonialism.

Third, the chapters in this volume help decenter the idea of empire by showing the internal complexity of imperial polities. As we have seen, the Iberian empires were less monolithic and more internally fragmented than the metropolitan image of empire may suggest. Xavier (Chapter 2) illustrates how the policy of conversion reshaped the Portuguese imperial order in Goa, Salcete, and Bardez, moving from a more pluralistic approach to local societies to one less so. Xavier thus demonstrates that the Portuguese imperial order had to balance the - sometimes aligned and sometimes divergent-interests of the Crown with those of the Church. Further, Patricia Souza de Faria (Chapter 4), 
by looking at the guardianship of orphans of Gentile parents, reveals that these tensions between the fiscal interests of the Crown and the spiritual interests of the Church tempered the policies of conversion. She argues that non-Christian merchants, craftsmen, and shopkeepers used their positions to take advantage of the tensions between the secular and religious interests of the Estado da Índia and were able to uphold their customs and gain certain exemptions from Christian obligations. Perez (Chapter 3) similarly illustrates how indigenous jurisdiction in the Philippines resulted from the way in which conflicts between the encomenderos, natives, the Crown, and the Bishopric of Manila were ultimately negotiated. The competing interests within the Spanish colonial structure gave indigenous principales a way to build alliances and reshape their relations with the Crown and the colonial government of the archipelago.

Fourth, this volume also discusses the ways in which, more than providing laws and rules for application, 'European law' provided a 'grammar' that allowed the production of new norms according to new conditions. Miguel Rodrigues Lourenço (Chapter 7) discusses the construction of a specific vocabulary for religious transgression and dissent by the Goa Inquisition, which was built on a long tradition of categories to address and punish religious offences-heresy, idolatry, sect, superstition, etc. The tendency of Goan converts, the cristãos da terra, to revert to their former rituals and practices-dressing in the "manner of a 'Moor", removing their shoes when entering temples "in the manner of the Gentiles", or washing their bodies "in the fashion of the infidels", to name some examples-led the Holy Office to create gentilidade as a category of offence that could allow the inspection of a variety of behaviors, rituals, and ceremonies that reflected the specific circumstances of Christians in the territory. Rômulo da Silva Ehalt (Chapter 8) studies the role of missionary casuistry in defining the rules for professing the faith in Japan during the persecution of Christians under Tokugawa rule: could Japanese Christians lie about their faith if it meant saving their own lives and that of their co-religionists? The answer to this question - central to avoiding sins of commission - was important for guiding the practice of Christians in Japan and thus missionaries had to find ways to reconcile the needs generated by local conditions with the sources of normative authority. Lastly, Marina Torres Trimállez (Chapter 9) highlights the different sources of authority, and the varying degrees of importance assigned to them, used by missionaries in China to argue for and against the use of headwear during mass and confession. Despite the existence of a papal authorization that, against Tridentine precepts, allowed the use of headwear during mass in China, this rule was subject to debate and revision by the missionaries themselves. Torres Trimállez shows how missionaries drew on available normative knowledge to design rules for the discussion and modification of 
Tridentine and papal rules and how, in turn, these discussions were built upon different sources of normative authority, ranging from experience and local custom to moral theology and divine and natural law.

Finally, the chapters of this volume also propose different methodological approaches to addressing local normativities. Xavier (Chapter 2) addresses the lack of written, archeological, and epigraphic sources for Goa by taking a 'regional approach' which makes use of anthropological studies of the broader West Konkan region of which it was a part. Also, as a way of overcoming the lack of pre-colonial sources, Camacho (Chapter 5) looks at anthropological research concerning the practice of bridewealth to understand the institutions of bugay and bigay-kaya in the Philippines. Coutinho Silva (Chapter 6) draws on the field of women's history to understand the transformation in marriage practices in Japan by looking at the way women's roles in the family and in society changed over time. Further, Perez (Chapter 3) and Lourenço (Chapter 7) use comparisons with the Iberian colonies in America to both fill gaps in knowledge and reveal regional variations in the treatment of similar problems. While Perez explores the literature on indigenous judicial systems in Spanish America to draw parallels to their development in the Philippines, Lourenço explores the treatment of cases of heresy and idolatry in Brazil to underscore the uniqueness of gentilidade as a category of religious offence by the Goa Inquisition.

Taken together, the chapters in this volume reveal that, even if the presence of the Iberian empires in Asia produced the disruption that set in motion a vast process of normative change, the outcome was not something that could be shaped in their image. Ultimately, the making of law in Iberian Asia was a decentralized process of normative production that tied different communities together, connected different layers of norms, and eventually shaped a wide variety of local orders.

\section{Bibliography}

Agüero, Alejandro, "Las Categorías Básicas de la Cultura Jurisdiccional", in Marta Lorente (ed.), De Justicia de Jueces a Justicia de Leyes: Hacia la España de 1870, Madrid 2007, 21-58.

Agüero, Alejandro, Castigar y Perdonar cuando Conviene a la República: La Justicia Penal de Córdoba del Tucuman, Siglos XVII YXVIII, Madrid 2008.

Alcock, Susan, Terence D’Altroy, Kathleen Morrisson and Karla Sinopoli (eds.), Empires: Perspectives from Archaeology and History, Cambridge 2001 (repr. Cambridge 2005). Angeles, F. Delor, "The Philippine Inquisition: A Survey", in Philippine Studies 28, no. 3 (1980): 253-283. 
Anghie, Antony, Imperialism, Sovereignty, and the Making of International Law, Cambridge 2005 .

Bastias Saavedra, Manuel, "Jurisdictional Autonomy and the Autonomy of Law: End of Empire and the Functional Differentiation of Law in 19th-Century Latin America", in Rechtsgeschichte - Legal History 26 (2018): 325-337.

Benton, Lauren, "The Legal Regime of the South Atlantic World, 1400-1750: Jurisdictional Complexity as Institutional Order", in Journal of World History 11, no. 1 (2000): 27-56.

Benton, Lauren. Law and Colonial Cultures: Legal Regimes in World History, 1400-1900, Cambridge 2004.

Benton, Lauren, A Search for Sovereignty: Law and Geography in European Empires 1400-1900, New York 2010.

Benton, Lauren, "AHR Forum: Law and Empire in Global Perspective: Introduction", in The American Historical Review 117, no. 4 (2012): 1092-1100.

Benton, Lauren, "In Defense of Ignorance: Frameworks for Legal Politics in the Atlantic World", in Owensby; Ross, Justice in a New World, 273-29o.

Benton, Lauren, "Made in Empire: Finding the History of International Law in Imperial Locations", in Leiden Journal of International Law 31, no. 3 (2018): 473-478.

Benton, Lauren and Richard Ross (eds.), Legal Pluralism and Empires, 1500-1850, New York 2013 .

Bethencourt, Francisco and Diogo Ramada Curto (eds.), Portuguese Oceanic Expansion, 1400-1800, New York 2007.

Biedermann, Zoltán, The Portuguese in Sri Lanka and South India: Studies in the History of Diplomacy, Empire and Trade, 1500-1650, Wiesbaden 2014.

Bouza, Fernando, Pedro Cardim and Antonio Feros (eds.), The Iberian World: 1450-1820, New York 2019.

Boxer, Charles R., Portuguese Society in the Tropics: The Municipal Councils of Goa, Macao, Bahia, and Luanda, 1510-1800, Madison 1965.

Boxer, Charles R., The Great Ship from Amacon. Macau 1988.

Boxer, Charles R., Igreja Militante e a Expansão Ibérica 1440-1770, São Paulo 2007.

Brockey, Liam Matthew, Journey to the East: The Jesuit Mission to China, 1579-1724, Cambridge 2007.

Brunero, Donna, Jack Fairey and Brian P. Farrell (eds.), Empire in Asia: A New Global History, London 2018.

Burbank, Jane and Frederick Cooper, Empires in World History: Power and the Politics of Difference, Princeton 2010.

Burbank, Jane and Frederick Cooper, "Rules of Law, Politics of Empire", in Lauren Benton and Richard Ross (eds.), Legal Pluralism and Empires, 1500-1850, New York 2013, 279-293. 
Cardim, Pedro and António Manuel Hespanha, "A Estrutura Territorial das duas Monarquia Ibéricas (Séculos XVI-XVIII)", in Barreto Xavier, Ângela, Federico Palomo and Roberta Stumpf, Monarquias Ibéricas em Perspectiva Comparada (Séculos XVI-XVIII), Lisboa 2018, 51-95.

Clavero, Bartolomé, Tantas Personas como Estados: Por una Antropología Política de la Historia Europea, Madrid 1986.

Clavero, Bartolomé, Antídora: Antropología Católica de la Economía Moderna, Milano 1991.

Coello de la Rosa, Alexandre, Jesuits at the Margins: Missions and Missionaries in the Marianas (1668-1769), Taylor and Francis 2015.

Cooper, Frederick, Colonialism in Question: Theory, Knowledge, History, Berkeley 2005.

Costa, Pietro, Iurisdictio: Semantica del Potere Politico nella Pubblicistica Medievale (1100-1433), Milano 2002.

Didier, Hugues, Le Portugais au Tibet: Les Premières Relations Jésuits (1624-1635), Paris 2002.

Disney, A. R., A History of Portugal and the Portuguese Empire: From Beginnings to 1807 , vol. 2. Cambridge 2009.

Disney, A. R., The Portuguese in India and other Studies, 1500-1700, Farnham 2009.

Donlan, Seán Patrick and Dirk Heirbaut (eds.), The Law's Many Bodies: Studies in Legal Hybridity and Jurisdictional Complexity, C. 1600-1900, Berlin 2015.

Duindam, Jeroen, Jill Harries, Caroline Humfress and Nimrod Hurvitz (eds.), Law and Empire: Ideas, Practices, Actors, Leiden 2013.

Duve, Thomas, "Rechtsgeschichte als Geschichte von Normativitätswissen?", in Augsberg, Gunnar Folke and Ino Schuppert (eds.), Wissen und Recht, Baden-Baden, forthcoming.

Duve, Thomas, "Von der Europäischen Rechtsgeschichte zu einer Rechtsgeschichte Europas in globalhistorischer Perspektive", in Rechtsgeschichte - Legal History Rg $20(2012), 18-71$.

Duve, Thomas, "Global Legal History a Methodological Approach", in Max Planck Institute for European Legal History Research Paper Series, no. 4 (2016).

Duve, Thomas, "Was ist Multinormativität? Einführende Bemerkungen”, in Rechtsgeschichte - Legal History 25 (2017): 88-101.

Duve, Thomas, "Pragmatic Normative Literature and the Production of Normative Knowledge in the Early Modern Iberian Empires (16th-17th Centuries)", in Duve, Thomas and Otto Danwerth (eds.), Knowledge of the Pragmatici: Legal and Moral Theological Literature and the Formation of Early Modern Ibero-America, Leiden 2020, 1-39.

Duve, Thomas, "What is Global Legal History?", in Comparative Legal History (2020): $1-43$. 
Duve, Thomas and Otto Danwerth (eds.), Knowledge of the Pragmatici:Legal and Moral Theological Literature and the Formation of Early Modern Ibero-America, Leiden 2020.

Duve, Thomas, José Luis Egío and Christiane Birr (eds.), The School of Salamanca: A Case of Global Knowledge Production, Leiden 2021.

Elliott, J. H., "A Europe of Composite Monarchies", in Past and Present 137, no. 1 (1992): 48-71.

Fairey, Jack, and Brian P. Farrell, "Reordering an Imperial Modern Asia", in Brunero, Donna, Jack Fairey and Brian P. Farrell (eds.), Empire in Asia: A New Global History, London 2018, 1-8.

Fisch, Jörg, "Law as a Means and as an End: Some Remarks on the Function of European and Non-European Law in the Process of European Expansion", in Mommsen, Wolfgang and Jaap de Moor (eds.), European Expansion and Law, Oxford 1992, 15-38.

Flannery, John M., The Mission of the Portuguese Augustinians to Persia and Beyond (1602-1747), Leiden 2013.

Flores, Jorge, "The Iberian Empires, 1400 to 1800 ", in Bentley, Jerry H., Sanjay Subrahmanyam and Merry Wiesner-Hanks (eds.), The Construction of a Global World, 14001800 CE, The Cambridge World History 6, Cambridge 2015, 271-296.

Garriga, Carlos, "Las Audiencias: Justicia y Gobierno de las Indias", in Barrios, Feliciano (ed.), El Gobierno de un Mundo: Virreinatos y Audiencias en la América Hispana, Cuenca 2004, 711-794.

Garriga, Carlos, “Orden Jurídico y Poder Político en el Antiguo Régimen”, in Istor. Revista de Historia Internacional 16 (2004): 3-44.

Garriga, Carlos, “¿De qué hablamos los Historiadores del Derecho cuando hablamos de Derecho?", in Revista Direito Mackenzie 14, no. 1 (2020).

Girgen, Jen, "The Historical and Contemporary Prosecution and Punishment of Animals", in Animal Law Review at Lewis \& Clark Law School 9, no. 1 (2003): 97-133.

Grossi, Paolo, El Orden Jurídico Medieval, Madrid 1995.

Gruzinski, Serge, Las Cuatro Partes del Mundo: Historia de una Mundialización, México D.F. 2010.

Halperin, Sandra and Ronen Palan, "Introduction: Legacies of Empire", in Halperin, Sandra and Ronen Palan, Legacies of Empire: Imperial Roots of the Contemporary Global Order, Cambridge 2015, 1-24.

Härter, Karl, “Das Heilige Römische Reich deutscher Nation als mehrschichtiges Rechtsystem 1495-1806", in Wendehorst, Stephan, Die Anatomie frühneuzeitlicher Imperien: Herrschaftsmanagement jenseits von Staat und Nation, Institutionen, Personal und Techniken, Berlin 2015, 327-347.

Hausser, Christian and Horst Pietschmann, "Empire: The Concept and its Problems in the Historiography on the Iberian Empires in the Early Modern Age", in Culture \& History Digital Journal 3, no. 1 (2014): 7-16. 
Herzog, Tamar, "What Natives Said and How Europeans Responded in Late-Seventeenth- and Eighteenth-Century Portuguese America", in Owensby, Brian P. and Richard J. Ross (eds.), Justice in a New World: Negotiating Legal Intelligibility in British, Iberian, and Indigenous America, New York 2018, 61-88.

Hespanha, António Manuel, História das Instituições: Épocas Medieval e Moderna, Coimbra 1982.

Hespanha, António Manuel, "Centro e Periferia nas Estruturas Administrativas do Antigo Regime", in Ler História 8 (1986).

Hespanha, António Manuel, Vísperas del Leviatán: Instituciones y Poder Político (Portugal, Siglo XVII), Madrid 1989.

Hespanha, António Manuel, La Gracia del Derecho: Economía de la Cultura en la Edad Moderna, Madrid 1993.

Hespanha, António Manuel, "Early Modern Law and the Anthropological Imagination of Old European Culture”, in Marino, John A., Early Modern History and the Social Sciences: Testing the Limits of Braudel's Mediterranean, Kirksville 2002, 191-204.

Hespanha, António Manuel, “Depois do Leviathan”, Almanack Braziliense 5 (2007): $55^{-66 .}$

Hespanha, António Manuel, “Antigo Regime nos Trópicos? Um Debate sobre o Modelo político do Império Colonial Português”, in Fragoso, João L. R. and Maria d. F. Gouvêa, Na Trama das Redes: Política e Negócios no Império Português, Séculos XVIXVIII, 43-93, Rio de Janeiro 2010.

Hespanha, António Manuel, "Uncommon Laws: Law in the Extreme Peripheries of an Early Modern Empire", in Zeitschrift der Savigny-Stiftung für Rechtsgeschichte: Germanistische Abteilung 130, no. 1 (2013): 180-204.

Hespanha, António Manuel, Como os Juristas viam o Mundo. 1550-1750: Direitos, Estados, Pessoas, Coisas, Contratos, Ações e Crimes, Lexington 2015.

Hespanha, António Manuel, "As Cores e a Institução da Ordem no Mundo de Antigo Regime", in Hespanha, António M. (ed.), A Ordem do Mundo e o Saber dos Juristas: Imaginários do Antigo Direito Europeu, Lisboa 2017, 341-370.

Hespanha, António Manuel, Filhos da Terra: Identidades Mestiças nos Confins da Expansão Portuguesa, Lisboa 2019.

Hespanha, António Manuel, "Is there a Place for a Separated Legal History? A Broad Review of Recent Developments on Legal Historiography", in Quaderni Fiorentini per la Storia del Pensiero Giuridico Moderno 48 (2019): 7-28.

Howe, Stephen, Empire: A Very Short Introduction, Oxford 2002.

Humphrey, Nicholas, "Bugs and Beasts Before the Law", in Humphrey, Nicholas (ed.), The Mind Made Flesh: Essays from the Frontiers of Psychology and Evolution, Oxford 2002, 235-254.

Koenigsberger, H. G., "Monarchies and Parliaments in Early Modern Europe Dominium Regale or Dominium Politicum et Regale", in Theory and Society 5, no. 2 (1978): 191-217. 
Koskenniemi, Martti, "Introduction: International Law and Empire: Aspects and Approaches", in Koskenniemi, Martti, Walter Rech and Manuel Jiménez Fonseca (eds.), International Law and Empire: Historical Explorations, Oxford 2017, 1-18.

Koskenniemi, Martti, Walter Rech, and Manuel Jiménez Fonseca (eds.), International Law and Empire: Historical Explorations, Oxford 2017.

Kumar, Krishan, Visions of Empire: How Five Imperial Regimes Shaped the World, Princeton 2019.

Maier, Charles S., Among Empires: American Ascendancy and its Predecessors, Cambridge 2006.

Mannori, Luca, "Justicia y Administración entre Antiguo y Nuevo Régimen”, in Revista Jurídica Universidad Autónoma de Madrid 15 (2007): 125-146.

Martínez Shaw, Carlos and Marina Alfonso Mola, "The Philippine Islands: A Vital Crossroads during the First Globalization Period", in Culture \& History Digital Journal 3, no. 1 (2014): 27-42.

Menegon, Eugenio, Ancestors, Virgins, \& Friars: Christianity as a Local Religion in Late Imperial China, Cambridge 2009.

Mommsen, Wolfgang J, "Introduction", in Mommsen, Wolfgang J. and Jaap de Moor (eds.), European Expansion and Law, Oxford 1992, 1-14.

Mommsen, Wolfgang J. and Jaap de Moor (eds.), European Expansion and Law: The Encounter of European and Indigenous Law in 19th-and 2oth-Century Africa and Asia, Oxford 1992.

Owensby, Brian Philip and Richard Jeffrey Ross (eds.), Justice in a New World: Negotiating Legal Intelligibility in British, Iberian, and Indigenous America, New York 2018.

Pagden, Anthony, Lords of all the World: Ideologies of Empire in Spain, Britain and France c. 1500-c.1800, New Haven 1995.

Pagden, Anthony, "Afterword: From Empire to Federation", in Balachandra Rajan and Elizabeth Sauer, Imperialisms Historical and Literary Investigations, New York 2004, 255-271.

Paiva, José Pedro, “The Inquisition Tribunal in Goa: Why and for What Purpose?" Journal of Early Modern History 21 (2017): 565-593.

Petit, Carlos, Pasiones del Jurista: Amor, Memoria, Melancolía, Imaginación, Madrid 1997.

Pitts, Jennifer, Boundaries of the International: Law and Empire, Cambridge 2018.

Roper, Louis H. and Bertrand van Ruymbeke (eds.), Constructing Early Modern Empires: Proprietary Ventures in the Atlantic World, 1500-1750, Leiden 2007.

Russell-Wood, A. J., R., "Patterns of Settlement in the Portuguese Empire", in Bethencourt, Francisco and Diogo R. Curto, Portuguese Oceanic Expansion, 1400-1800, 16196, New York 2007.

Spate, O. H. K., The Spanish Lake, Minneapolis 1979.

Subrahmanyam, Sanjay, "Connected Histories: Notes towards a Reconfiguration of Early Modern Eurasia”, in Modern Asia Studies 31, no. 3 (1997): 735-762. 
Subrahmanyam, Sanjay, "Written on Water: Designs and Dynamics in the Portuguese Estado da Índia”, in Alcock, Susan et al. (eds.), Empires: Perspectives from Archaeology and History, Cambridge 2001 (repr. Cambridge 2005), 42-69.

Subrahmanyam, Sanjay, The Portuguese Empire in Asia, 1500-1700: A Political and Economic History, Sussex UK 2012.

Subrahmanyam, Sanjay, Empires Between Islam and Christianity, 1500-1800, Albany 2019.

Thomaz, Luís Filipe, De Ceuta a Timor, Lisboa 1998.

Tomlins, Christopher, "The Many Legalities of Colonization: A Manifesto of Destiny for Early American Legal History", in The Many Legalities of Early America, Tomlins, Christopher and Bruce H. Mann, Chapel Hill 2001, 1-20.

Vallejo, Jesús, "Power Hierarchies in Medieval Juridical Thought: An Essay in Reinterpretation", in Ius Commune Sonderdruck (1992): 1-29.

Vallejo, Jesús, Ruda Equidad, Ley Consumada: Concepción de la Potestad Normativa, (1250-1350), Madrid 1992.

Vallejo, Jesús, "Acerca del Fruto del Árbol de los Jueces: Escenarios de la Justicia en la Cultura del Ius Commune", in Anuario de la Facultad de Derecho de la Universidad Autónoma de Madrid 2 (1998): 19-46.

Vallejo, Jesús, "El Cáliz de Plata: Articulación de Órdenes Jurídicos en la Jurisprudencia del Ius Commune", Revista de Historia del Derecho 38 (2009): 1-13.

Wendehorst, Stephan (ed.), Die Anatomie frühneuzeitlicher Imperien: Herrschaftsmanagement jenseits von Staat und Nation Institutionen, Personal und Techniken, Berlin 2015 .

Weststeijn, Arthur, "Provincializing Grotius: International Law and Empire in a Seventeenth-Century Malay Mirror", in Koskenniemi, Martti, Walter Rech and Manuel Jiménez Fonseca (eds.), International Law and Empire: Historical Explorations, Oxford 2017, 21-38.

Xavier, Ângela Barreto and Fernanda Olival, “O Padroado da Coroa de Portugal: Fundamentos e Práticas", in Xavier; Palomo; Stumpf, Monarquias Ibéricas em Perspectiva Comparada (Séculos XVI-XVIII), 123-160.

Xavier, Ângela Barreto, Federico Palomo and Roberta Stumpf (eds.), Monarquias Ibéricas em Perspectiva Comparada (Séculos XVI-XVIII): Dinâmicas Imperiais e Circulação de Modelos Político-Administrativos, Lisboa 2018.

Zamora, Romina, Casa Poblada y Buen Gobierno: “Oeconomía” Católica y Servicio Personal en San Miguel de Tucumán, Siglo XVIII, Buenos Aires 2017. 